\title{
How to Create a Successful Language Lesson
}

\section{Suping Liu}

International Education Department, Beijing Information Technology College, Beijing, China

\begin{abstract}
As teachers, especially language teachers, we do hope that our lessons can be deeply appreciated by our students. But how can we create a successful lesson? What are the key factors involved in teaching which affect the result of our lesson? What should we do? During the four weeks of visiting schools and colleges and attending lectures given by the professors in UK, I do think I have gained a lot. The more I think of the life and ways of studying here, the more I feel I should write something on this topic.
\end{abstract}

Key words: a successful lesson; the needs of students; class design; charm

\section{Introduction}

To begin with, what is a successful lesson? Maybe there are various criteria to define a successful lesson. But in my opinion, simply and fundamentally, the answer might be a lesson that could draw the students' attention and arouse their interests in language; a lesson that could develop their skills in listening, speaking, reading and writing; a lesson that the students feel time is so short and they long to learn more. And then, how can we create a successful lesson? I think it is mainly decided by three critical factors: (1) the contents of the lesson; (2) class design; (3) the charm of the teacher. Now I would like to illustrate my viewpoints in detail.

\section{Choose the Right Contents of the Lesson by Considering the Needs of Students}

If you want to be a popular teacher and to create a successful lesson, you should know the knowledge of your area quite well. That is, you should be well equipped and be eager to update the knowledge of the field with the development of the time. We all know that the content of the lesson should be in agreement with the syllabus. When you choose the content of teaching, the first thing to consider is the requirements of the syllabus, which is common sense to any teacher. Apart from this, what else should we think of? The answer is bringing your students to you instead of taking your materials to your students. While choosing the content, the most important thing is to think of your audience---your students. Who are they? What's their level of knowledge? How about their language level? What do they want? ...... Among all these questions, I think being aware of the needs of your students is the most important one. I once interviewed some of the teachers here who gave us lessons and whose lessons are popular among our teachers. One of them told me, "When I choose the materials for you, the most important thing that I consider is what you might want to know, and topics that you might be interested in besides the purpose of coming here. This is one of the key points to a successful lesson." On the contrary, if you lack the understanding of your students, you may not satisfy your students even though you have made great efforts in preparing your lessons.

\section{Design Your Class and Grasp the Right Time of Presenting Materials}

Copyright (C 2021 by author(s) and Frontier Scientific Research Publishing Inc.

This work is licensed under the Creative Commons Attribution International License (CC BY 4.0).

http://creativecommons.org/licenses/by/4.0/ 
It cannot be considered a good lesson if you have only chosen the right topic and prepared some interesting materials for the students but not designed your class properly or prepared your lesson well. Which part should go first, and which part should go last? How to present your materials? Brain theory tells us that students find it easier to learn if new material can be tied into something they already know. Then what is the right time for the students to have the material? What kind of activities do you ask your students to do to consolidate their knowledge and arouse their interests as well as develop their skills? So in some way, class design can be regarded as an art in teaching. There are no definite principles for designing a successful lesson, simply because there are so many different factors, complicated teaching and learning background, and various situations that need to be considered, such as the purpose of learning, the contents of teaching, the students, the time of having lessons as well as the personalities of different teachers etc. So the only standard of designing a successful lesson is doing the right thing at the right time, based on the specified situations you come across, which means every step of your lesson should tightly catch the students interests and attention, and give them a quick paced impression. Do present materials until you have stimulated their interest and hunger for knowledge, that is, give when they need just as feed when they are hungry. Plan your lesson carefully and try to vary activities during the 90-minute class period to keep students focused during a lengthy lesson. Help your students establish a connection between what they have learned in school and their experience in the outside world. And help students demonstrate critical thinking.

I remembered once I had Ms. Anneliese's lesson which is about Shakespeare. First she let us all sit in a comparatively small circle, including her, and then we began to talk about what we knew freely. Actually, we did know something about Shakespeare, because we had learned some of his sonnets and plays in university. And then her questions went further and deeper when she found our discussion nearly came to an end. "Did Shakespeare go to university?" "Did he really write all those plays, sonnets and poems?" "What did he do before becoming a professional actor and dramatist?" "Why did Shakespeare leave Stratford for London?" These questions aroused our great interests and we were eager to know the unfamiliar things about Shakespeare. Just at this time, Ms. Anneliese handed out the materials she prepared beforehand and began her lecture on Shakespeare. After she finished, she provided us with some websites and assigned us even more challenging work---try to find out more about the Bard by using internet. There was so much information about Shakespeare on the internet and I had hardly finished half of them when it was time to end the lesson. What a pity! How I wish the lesson could be longer! From the example I experienced, we can see that a successful lesson requires the teacher's hard work before class---to design, to prepare, to select, to direct, etc. and also to be well paced. Furthermore, you should have some knowledge on psychology in order to understand your students better.

\section{Charm of the Teacher}

Although the selected content and courses are carefully prepared and designed, the teachers themselves can also affect the quality of successful courses. Do you express your ideas logically and clearly? Are the words or sentences you applied in your lecture suitable for the language level of your students? Do you speak them correctly with nice pronunciation and intonation? Are you good at using body language and facial expressions? How about the tone of your speaking? Do you care about your talking style and personal behavior? Do you fully devote yourself to the lesson and give your lesson with emotion? Are you sincere and treat your students with respect? How do you deal with emergencies in class smartly? As a qualified teacher to create a successful lesson, you should consider these questions often. I once observed a physics lesson given by Mr. Davis at George Abbot School, which left me with very deep impression. He seemed to be a forever happy, lively, humorous and polite young gentleman. He looked energetic, smart and confident when standing before his students. The topic that day was "The speed of Sound". He was giving his lesson when it began to rain outside. The lightening and thunder attracted some of the students' attention as well as Mr. Davis'. I'm sure if I were Mr. Davis, I might say to the 
absent-minded students angrily, "Haven't you seen rain before?" and ask them be back to my lesson. But Mr. Davis' behavior is very different. He didn't stop his students. On the contrary, he looked just as excited as his students, "Oh, thunderstorm!" he shouted with excitement and then enjoyed the musical sound of rain. Then he came to a question, "Now class. Who can tell me which is faster, the speed of thunder or the lightening?" The students quickly moved their attention to the question and began to discuss it enthusiastically. I should say Mr. Davis knew his students so well and he did things with the students instead of against them. He was so smart to make use of the disadvantages and convert them into useful one. After he finished his lesson, the students went to the playground to do an experiment to measure the relationship between distance, time and the speed of sound. It was still raining but none of them seemed to notice, instead, they did their experiment in high spirit. I was deeply moved by this scene. Without love and responsibility for his students and his job, can he do it with all his heart and soul? So love and a sense of responsibility are very important and essential for a teacher and a successful lesson.

\section{Conclusions}

All in all, to be a good teacher and to create a successful lesson, you should love your job and have strong responsibility for the students and the work. You should be aware of the art and techniques of education. In short, understand your students, be a good teacher.

\section{Conflicts of Interest}

The author declares no conflicts of interest regarding the publication of this paper.

\section{References}

[1] Wang S.P. and Li Y.J. (2009). How to Complete a Successful College English Intensive Reading Course. Intelligence, (18): 75-76.

[2] Chen J. Z. (1982). A Successful Ideological and Moral Class. People's education, (4): 14-16.

[3] Wendy F. (1977). A Successful Lesson. The Australian Journal of Indigenous Education, 5(2): 37-38. 